\title{
Dynamics of transparent exopolymer particles (TEP) during the VAHINE mesocosm experiment in the New Caledonian lagoon
}

\author{
Ilana Berman-Frank ${ }^{1}$, Dina Spungin ${ }^{1}$, Eyal Rahav ${ }^{1,2}$, France Van Wambeke ${ }^{3}$, Kendra Turk-Kubo ${ }^{4}$, and \\ Thierry Moutin ${ }^{3}$ \\ ${ }^{1}$ The Mina and Everard Goodman Faculty of Life Sciences, Bar-Ilan University, Ramat Gan, 5290002, Israel \\ ${ }^{2}$ National Institute of Oceanography, Israel Oceanographic and Limnological Research, Haifa, 31080, Israel \\ ${ }^{3}$ Aix Marseille Université, CNRS/INSU, Université de Toulon, IRD, Mediterranean Institute of Oceanography (MIO) \\ UM110, 13288, Marseille, France \\ ${ }^{4}$ Ocean Sciences Department, University of California, Santa Cruz, 1156 High Street, Santa Cruz, CA 95064, USA \\ Correspondence to: Ilana Berman-Frank (ilana.berman-frank@biu.ac.il)
}

Received: 29 November 2015 - Published in Biogeosciences Discuss.: 18 January 2016

Revised: 1 May 2016 - Accepted: 5 May 2016 - Published: 1 July 2016

\begin{abstract}
In the marine environment, transparent exopolymeric particles (TEP) produced from abiotic and biotic sources link the particulate and dissolved carbon pools and are essential vectors enhancing vertical carbon flux. We characterized spatial and temporal dynamics of TEP during the VAHINE experiment that investigated the fate of diazotroph-derived nitrogen and carbon in three replicate dissolved inorganic phosphorus (DIP)-fertilized $50 \mathrm{~m}^{3}$ enclosures in the oligotrophic New Caledonian lagoon. During the 23 days of the experiment, we did not observe any depthdependent changes in TEP concentrations in the three sampled depths $(1,6,12 \mathrm{~m})$. TEP carbon (TEP-C) content averaged $28.9 \pm 9.3$ and $27.0 \pm 7.2 \%$ of total organic carbon (TOC) in the mesocosms and surrounding lagoon respectively and was strongly and positively coupled with TOC during P2 (i.e., days 15-23). TEP concentrations in the mesocosms declined for the first 9 days after DIP fertilization $(\mathrm{P} 1=$ days $5-14)$ and then gradually increased during the second phase. Temporal changes in TEP concentrations paralleled the growth and mortality rates of the diatomdiazotroph association of Rhizosolenia and Richelia that predominated the diazotroph community during P1. By P2, increasing total primary and heterotrophic bacterial production consumed the supplemented $\mathrm{P}$ and reduced availability of DIP. For this period, TEP concentrations were negatively correlated with DIP availability and turnover time of DIP $\left(T_{\mathrm{DIP}}\right)$, while positively associated with enhanced alkaline phosphatase activity (APA) that occurs when the microbial
\end{abstract}

populations are $\mathrm{P}$ stressed. During P2, increasing bacterial production (BP) was positively correlated with higher TEP concentrations, which were also coupled with the increased growth rates and aggregation of the unicellular cyanobacterial Group C (UCYN-C) diazotrophs that bloomed during this period. We conclude that the composite processes responsible for the formation and breakdown of TEP yielded a relatively stable TEP pool available as both a carbon source and facilitating aggregation and flux throughout the experiment. TEP were probably mostly influenced by abiotic physical processes during $\mathrm{P} 1$, while biological activity (BP, diazotrophic growth and aggregation, export production) mainly impacted TEP concentrations during P2 when DIP availability was limited.

\section{Introduction}

The cycling of carbon (C) in the oceans is a complex interplay between physical, chemical, and biological processes that regulate the input and the fate of carbon within the ocean. An essential process driving the flux of carbon and other organic matter to depth, and enabling long-term sequestration and removal of carbon from the atmosphere, is the biological pump that drives organic $\mathrm{C}$ formed during photosynthesis to the deep ocean. This process, termed export production (Eppley and Peterson, 1979), is facilitated via physical inputs of "new" nutrients (e.g., nitrogen, phosphorus, silica, trace 
metals) into the euphotic zone from either external sources (deep mixing of upwelled water, river discharge, dust deposition, and anthropogenic inputs) or via biological processes. One such process is microbial $\mathrm{N}_{2}$ fixation that converts biologically unavailable dinitrogen $\left(\mathrm{N}_{2}\right)$ gas into bioavailable forms of nitrogen and enhances the productivity of oligotrophic oceanic surface waters that are often limited by nitrogen (Capone, 2001; Falkowski, 1997).

Marine $\mathrm{N}_{2}$ fixation is performed by diverse prokaryotic organisms comprised predominantly of autotrophic cyanobacteria and heterotrophic bacteria (Zehr and Kudela, 2011). To supply the energetically expensive process of converting $\mathrm{N}_{2}$ to ammonia (Mulholland and Capone, 2000; Postgate and Eady, 1988; Stam et al., 1987), these organisms must obtain energy from either photosynthesis (cyanobacteria) or from bioavailable organic carbon compounds within the aquatic milieu (heterotrophic bacteria and mixotrophs). The total organic carbon (TOC) in the ocean contains dynamic particulate organic carbon (POC) and dissolved organic carbon (DOC) pools. These are supplied by biotic sources and are broken down into organic C-containing marine microgels which include transparent polymeric particles (TEP). TEP are predominantly acidic polysacchridic organic particles ranging in size from $\sim 0.45$ to $>300 \mu \mathrm{m}$ and are found in both marine and freshwater habitats (Passow, 2002). Both biotic and abiotic processes form aquatic TEP that are routinely detected by staining with Alcian Blue (Alldredge et al., 1993; Passow and Alldredge, 1995). Abiotic TEP occur by coagulation of colloidal precursors in the pool of dissolved organic matter (DOM) and from planktonic debris (Passow, 2002; Verdugo and Santschi, 2010) that may be stimulated by turbulence or by bubble adsorption (Logan et al., 1995; Passow, 2002; Zhou et al., 1998). Biotically TEP form from extracellular secretion or mucilage in algae and bacteria and from grazing and microbial breakdown of larger marine snow particles (reviewed in Bar-Zeev et al., 2015; Passow, 2002).

TEP are light and buoyant (Azetsu-Scott and Passow, 2004); yet, once formed, TEP sticky nature enhances and consolidates the formation of larger aggregates such as marine/lake snow, providing favorable environments for diverse microorganisms (Engel, 2004; Passow, 2002). Sedimentation of TEP-associated hot spots from the surface are important for transporting particulate organic material and microorganisms to deeper waters (Azam and Malfatti, 2007; Bar-Zeev et al., 2009; Smith and Azam, 1992). During sedimentation, TEP can also function as a direct source of carbon and other nutrients for higher trophic level organisms such as protists, micro-zooplankton, and nekton (Engel, 2004; Passow, 2002).

TEP production can be enhanced in late phases of algal blooms and in senescent or nutrient-stressed phytoplankton (Berman-Frank et al., 2007; Engel, 2004; Grossart et al., 1997; Passow, 2002). Thus, TEP in oligotrophic waters provide a source of available carbon to fuel microbial food webs (Azam and Malfatti, 2007) that typically succeed autotrophic blooms. TEP-based aggregates or marine-snow- containing TEP typically have high carbon (C): nitrogen (N) ratios (Berman-Frank and Dubinsky, 1999; Wood and Van Valen, 1990), which can also fuel $\mathrm{N}_{2}$ fixation by heterotrophic diazotrophs (Benavides et al., 2015; Rahav et al., 2013).

The VAHINE project was designed to examine the fate/s of "newly" fixed $\mathrm{N}$ by diazotrophs or diazotroph-derived $\mathrm{N}$ in the pelagic food web using large mesocosms in the oligotrophic tropical lagoon of New Caledonia where diverse diazotrophic populations have been observed (Biegala and Raimbault, 2008; Bonnet et al., 2016b; Dupouy et al., 2000; Garcia et al., 2007; Rodier and Le Borgne, 2008, 2010). One of the major questions addressed during VAHINE was whether diazotroph blooms significantly modify the stocks, fluxes, and ratios of biogenic elements $(\mathrm{C}$, $\mathrm{N}, \mathrm{P}, \mathrm{Si}$ ) and the efficiency of carbon export. To this end, the three large-volume $\left(\sim 50 \mathrm{~m}^{3}\right)$ mesocosms containing ambient lagoon waters were fertilized with $0.8 \mu \mathrm{molL}^{-1}$ dissolved inorganic phosphorus (DIP), and multiple parameters were measured inside and outside of the mesocosms for 23 days (details of parameters and experimental setup in Bonnet et al., 2016b). Within the VAHINE framework, our specific objectives were as follows: (1) to examine the spatial and temporal dynamics of TEP; (2) to determine whether TEP content was regulated by nutrient status in the mesocosms - specifically DIP availability; (3) to examine the relationship between TEP content, particulate and dissolved carbon, and primary or heterotrophic bacterial production; and (4) to elucidate whether TEP provided a source of energy for diazotrophs/bacteria/mixotrophs in mesocosms.

\section{Methods}

\subsection{Study site, mesocosm description, and sampling strategy}

Three large-volume $\left(\sim 50 \mathrm{~m}^{3}\right)$ mesocosms were deployed at the exit of the oligotrophic New Caledonian lagoon $\left(22^{\circ} 29.10^{\prime} \mathrm{S}-166^{\circ} 26.90^{\prime} \mathrm{E}\right)$, from 13 January 2013 (day 1) to 4 February 2013 (day 23). The complete description of the mesocosm design and deployment, as well as the sampling strategy, is detailed in Bonnet et al. (2016b). The mesocosms were supplemented with $0.8 \mu \mathrm{molL} \mathrm{L}^{-1} \mathrm{KH}_{2} \mathrm{PO}_{4}$ (hereafter referred to as DIP fertilization) between day 4 and day 5 of the experiment to promote $\mathrm{N}_{2}$ fixation. Samples were collected during the early morning of each day for 23 days with a clean Teflon pumping system from three selected depths ( 1 , $6,12 \mathrm{~m}$ ) in each mesocosm (M1, M2, and M3) and outside (hereafter called "lagoon waters" - O). Based on the results of different biogeochemical and biological parameters during VAHINE (Berthelot et al., 2015; Bonnet et al., 2016a; Turk-Kubo et al., 2015), three specific periods were discerned (see detailed description in Sect. 3.1) within which we have also investigated TEP dynamics: days 2-4 (P0) 
are the pre-fertilization days when the DIP concentrations were $0.02-0.05 \mu \mathrm{mol} \mathrm{L}^{-1} \mathrm{PO}_{4}^{3-}$ and combined dissolved inorganic nitrogen concentrations were extremely low; days 5-14 (P1); after fertilization on day 5, the $\mathrm{PO}_{4}^{3-}$ concentrations were $\sim 0.8 \mu \mathrm{mol} \mathrm{L}^{-1}$ and diazotrophic populations were dominated by diatom-diazotroph associations. The second stage of the experiment (P2) from days 15 to 23 was characterized by simultaneous increase in primary and bacterial production as well as in $\mathrm{N}_{2}$ fixation rates, which averaged $27.7 \mathrm{nmol} \mathrm{NL}^{-1} \mathrm{~d}^{-1}$ (Berthelot et al., 2015) and diazotrophic populations comprised primarily of the unicellular UCYN-C (Turk-Kubo et al., 2015).

\subsection{TEP quantification}

Water samples $(100 \mathrm{~mL})$ were gently $(<150 \mathrm{mbar})$ filtered through $0.45 \mu \mathrm{m}$ polycarbonate filters (GE Water \& Process Technologies). Filters were then stained with a solution of $0.02 \%$ Alcian Blue $(\mathrm{AB})$ and $0.06 \%$ acetic acid ( $\mathrm{pH}$ of 2.5). The excess dye was removed by a quick deionized water rinse. Filters were then immersed in sulfuric acid $(80 \%)$ for $2 \mathrm{~h}$, and the absorbance at $787 \mathrm{~nm}$ was measured spectrophotometrically (CARY 100, equipped with an integrated sphere, Varian). AB was calibrated using different volumes of purified polysaccharide GX (Passow and Alldredge, 1995). TEP concentrations ( $\mu \mathrm{g}$ xanthan gum [GX] equivalents $\mathrm{L}^{-1}$.) were measured according to Passow and Alldredge (1995). Total TEP content in the mesocosms was calculated by integrating the weighted average of the TEP concentrations per depth and multiplying it by the specific volume of each mesocosm. To estimate the role of TEP in C cycling, the total amount of TEP-C was calculated for each mesocosm, using the volumetric TEP concentrations at each depth, the specific volume per mesocosm, and the conversion of GX equivalents to carbon, applying the revised factor of 0.63 based on empirical experiments from both natural samples from different oceanic areas and phytoplankton cultures (Engel, 2004).

\subsection{Total organic carbon (TOC), particulate organic carbon (POC), dissolved organic carbon (DOC)}

Samples for TOC concentrations were collected in duplicate from $6 \mathrm{~m}$ in each mesocosm and in lagoon waters in precombusted sealed glassware flasks, acidified with $\mathrm{H}_{2} \mathrm{PO}_{4}$ and stored in the dark at $4{ }^{\circ} \mathrm{C}$ until analysis. Samples were analyzed on a Shimadzu TOC-V analyzer with a typical precision of $2 \mu \mathrm{molL}^{-1}$. Samples for POC concentrations were collected by filtering $2.3 \mathrm{~L}$ of seawater through a precombusted $\mathrm{GF} / \mathrm{F}$ filter $\left(450^{\circ} \mathrm{C}\right.$ for $4 \mathrm{~h}$ ), combusted and analyzed on an EA $2400 \mathrm{CHN}$ analyzer. DOC concentrations were calculated as the difference between TOC and POC concentrations. Fully detailed methodologies and data are available in Berthelot et al. (2015).

\subsection{Dissolved inorganic phosphorus (DIP) and alkaline phosphatase activity (APA)}

The determination of DIP concentrations is detailed in Berthelot et al. (2015). Samples for DIP were collected from each of the three depths in M1, M2, and M3 and lagoon waters $(\mathrm{O})$ in $40 \mathrm{~mL}$ glass bottles, and stored in $-20^{\circ} \mathrm{C}$ until analysis. DIP concentration was determined using a segmented flow analyzer according to Aminot and Kérouel (2007). The alkaline phosphatase activity (APA) was measured from the same depths and sites using the analog substrate methylumbelliferone phosphate (MUF-P, $1 \mu \mathrm{M}$ final concentration; SIGMA) (Hoppe, 1983). Full details of the measurements and analyses are described in Van Wambeke et al. (2016).

\subsection{Chlorophyll $a(\mathrm{Chl} a)$, primary production (PP), and DIP turnover time}

Chlorophyll $a$ (Chl $a$ ) concentrations were determined by the non-acidification method as described in Berthelot et al. (2015). Primary production (PP) rates and DIP turnover time ( $T_{\mathrm{DIP}}$, i.e., the ratio of $\mathrm{PO}_{4}^{-3}$ concentration and uptake) were measured using the ${ }^{14} \mathrm{C} /{ }^{33} \mathrm{P}$ dual labeling method (Duhamel et al., 2006). $60 \mathrm{~mL}$ bottles were amended with ${ }^{14} \mathrm{C}$ and ${ }^{33} \mathrm{P}$ and incubated for $3-4 \mathrm{~h}$ under ambient light and temperature. This was followed by the addition of $50 \mu \mathrm{L}$ of $\mathrm{KH}_{2} \mathrm{PO}_{4}$ solution $\left(10 \mathrm{mmol} \mathrm{L}^{-1}\right)$ to stop ${ }^{33} \mathrm{P}$ assimilation. Samples were then kept in the dark to stop ${ }^{14} \mathrm{C}$ uptake. Samples were filtered on $0.2 \mu \mathrm{m}$ polycarbonate membrane filters, and counts were done using a Packard Tri-Carb ${ }^{\circledR}$ 2100TR scintillation counter. PP and $T_{\mathrm{DIP}}$ were calculated according to Moutin et al. (2002).

\subsection{Bacterial production (BP)}

Heterotrophic bacterial production (BP) was estimated using the ${ }^{3} \mathrm{H}$-leucine incorporation technique (Kirchman, 1993), adapted to the centrifuge method (Smith and Azam, 1992). The complete methodology including enumeration of heterotrophic bacterial abundances (BA) by flow cytometry is detailed in Van Wambeke et al. (2016).

\section{$2.7 \quad \mathrm{~N}_{2}$ fixation, diazotrophic abundance, and growth rates}

$\mathrm{N}_{2}$ fixation rates were determined daily on ambient waters from mesocosms and the lagoon. Samples were spiked with $99 \%{ }^{15} \mathrm{~N}_{2}$-enriched seawater (Mohr et al., 2010), incubated in situ under ambient light and seawater temperatures as detailed in Berthelot et al. (2015) and Bonnet et al. (2016a).

Data and protocols of sampling for diazotrophic abundance and calculation of their respective growth rates are detailed fully in Turk-Kubo et al. (2015). Briefly, samples (from $6 \mathrm{~m}$ only) were collected every other day from the mesocosms, and from the lagoon waters. DNA was extracted and nine diazotrophic phylotypes were identified using quan- 
titative polymerase chain reactions (qPCRs). The targeted diazotrophs were two unicellular diazotrophic symbionts of different Braarudosphaera bigelowii strains, UCYN-A1, UCYN-A2; free-living unicellular diazotroph cyanobacterial phylotypes UCYN-B (Crocosphaera sp.), and UCYN$\mathrm{C}$ (Cyanothece sp. and relatives); Trichodesmium spp.; and three diatom-diazotroph associations (DDAs), Richelia associated with Rhizosolenia (Het-1), Richelia associated with Hemiaulus (Het-2), Calothrix associated with Chaetoceros (Het-3), and a widespread gamma-proteobacterial phylotype $\gamma$-24774A11. Abundances are reported as nifH copies $\mathrm{L}^{-1}$ as the number of nifH copies per genome in these diazotrophs is uncertain. Growth and mortality rates were calculated for individual diazotrophs inside the mesocosms when abundances were higher than the limit of quantification for two consecutive sampling days as detailed in Turk-Kubo et al. (2015).

\subsection{Microscopic analyses}

The detailed method for sampling for microscopic analyses is described in Bonnet et al. (2016a). Phytoplankton were visualized using a Zeiss Axioplan (Zeiss, Jena, 6 Germany) epifluorescence microscope fitted with a green (510$560 \mathrm{~nm}$ ) excitation filter, which targeted the Richelia and the UCYN phycoerythrin-rich cells. The diatom-diazotroph association Rhizosolenia-Richelia were imaged in bright-field microscopy.

\subsection{Statistical analyses}

Statistical analyses were carried out with XLSTAT, a Microsoft Office Excel based software. A Pearson correlation coefficient test was applied to examine the association between two variables (TEP vs. physical, chemical, or physiological variable) after linear regressions or log transformation of the data. The nonparametric Kruskal-Wallis one-way analysis of variance was applied to compare between TEP dynamics from each of the different phases. A confidence level of $95 \%(\alpha-0.05)$ was used. More details can be found in the supporting information.

\section{Results and discussion}

\subsection{General context and spatial and temporal dynamics of TEP}

The VAHINE experiment was designed to induce and follow diazotrophic blooms and their fate within an oligotrophic environment (Bonnet et al., 2016b). Our specific objectives of investigating TEP dynamics were thus examined within the general context and aims of the large experiment. The first stage of the experiment involved the enclosure of the lagoon waters and 3 days of equilibration of the system ( $\mathrm{P} 0$ - prefertilization days 2-4). At this initial stage the total Chl $a$ concentrations averaged around $0.2 \mu \mathrm{gL}^{-1}$ in the lagoon wa- ter and in the mesocosms and the phytoplankton consisted of diverse representatives from the cyanobacteria (Prochlorococcus, Synechococcus), and diatoms such as Pseudosolenia calcar-avis (Leblanc et al., 2016). During P0, the most abundant members of the diazotrophic community in the lagoon waters were Richelia-Rhizosolenia (Het-1), the unicellular UCYN-A1, UCYN-A2, UCYN-C, and the filamentous Trichodesmium (Turk-Kubo et al., 2015).

Fertilization of the mesocosms with DIP on day 4 stimulated a two-stage response by the diazotrophic community that was further reflected by many of the measured chemical and biological parameters (Berthelot et al., 2015; Bonnet et al., 2016a, b; Turk-Kubo et al., 2015). After fertilization, from day 5 through day 14 (P1), excluding a significant increase in $\mathrm{N}_{2}$ fixation rates, the functional community-wide biological responses (Chl $a$, PP, BP, BA) remained relatively low and similar to the values for $\mathrm{P} 0$ and for P1 in the outside lagoon waters (Berthelot et al., 2015; Leblanc et al., 2016; Van Wambeke et al., 2016). The autotrophic community during P1 was comprised of picophytoplankton such as Prochlorococcus Synechococcus, micro- and nanophytoplankton including dinoflagellates, and a diverse diatom community (Chaetoceros, Leptocylindrus, Cerataulina, Guinardia, and Hemiaulus) (Leblanc et al., 2016). Diatom-diazotroph associations (DDAs), predominantly Richelia-Rhizosolenia (Het-1), dominated the diazotroph community in the mesocosms (Turk-Kubo et al., 2015), although it still only contributed from 2 to $\sim 8 \%$ of the total diatom biomass in P0 and P1 respectively (Leblanc et al., 2016). These DDAs were succeeded during the last 9 days (day 15 to 23 termed P2) by a large bloom of unicellular diazotrophs characterized predominantly as UCYN-C (Turk-Kubo et al., 2015).

The final stage of the experiment (P2, days 15-23) was characterized by significantly enhanced values for many biological parameters including $\mathrm{N}_{2}$ fixation rates, $\mathrm{Chl} a$, PP, $\mathrm{BA}, \mathrm{BP}$, and particulate organic carbon and nitrogen compared to their respective average values in P1 (Bonnet et al., 2016a; Leblanc et al., 2016; Van Wambeke et al., 2016). In all three mesocosms, a significant bloom of UCYN-C developed (day 11 - M1, day 13 - M2, day $15-$ M3) and remained dominant representatives of the diazotroph community until day 23 (Turk-Kubo et al., 2015). The ambient autotrophic community responded to the input of new $\mathrm{N}$, and the transfer of diazotroph-derived $\mathrm{N}$ was demonstrated and seen in increasing abundance of Synechococcus, picoeukaryotes, and the non-diazotrophic diatoms Navicula and Chaetoceros spp. (Bonnet et al., 2016a; Leblanc et al., 2016; Van Wambeke et al., 2016). Thus the extremely high $\mathrm{N}_{2}$ fixation rates during this experiment provided sufficient new $\mathrm{N}$ to yield high Chl $a$ concentrations $\left(>1.4 \mu \mathrm{g} \mathrm{L}^{-1}\right.$ ) and rates of PP $\left(>2 \mu \mathrm{molCL} \mathrm{CL}^{-1} \mathrm{~d}^{-1}\right)$ (Berthelot et al., 2015). 


\section{Dynamics of TEP}

TEP concentrations for the entire experimental period ranged from $\sim 22$ to $1200 \mu \mathrm{g} \mathrm{GXL}^{-1}$. In each mesocosm and in the lagoon waters $(\mathrm{O})$, the TEP concentrations were similar for the three sampled depths within the $15 \mathrm{~m}$ water column, with an overall average of $350 \pm 180 \mu \mathrm{g} \mathrm{GXL}^{-1}$ (Fig. S1 in the Supplement). Temporally, TEP concentrations generally followed the three distinct periods (P0, P1, P2) that coincided with the described experimental phases characterized from the diazotrophic populations and the biogeochemical and biological (production) parameters (Berthelot et al., 2015; Bonnet et al., 2016a; Leblanc et al., 2016; Turk-Kubo et al., 2015; Van Wambeke et al., 2016) (Figs. 1, S1). Following the enclosure of the lagoon water in the mesocosms (day 2), TEP concentrations increased from the lowest volumetric concentrations (averaging $\sim 50 \mu \mathrm{g} \mathrm{GXL}^{-1}$ ) measured on day 2 to reach maximum concentrations in each of the mesocosms (average of $\sim 800 \mu \mathrm{g} \mathrm{GXL}^{-1}$ ) on day $5, \sim 15 \mathrm{~h}$ after the mesocosms were fertilized with DIP (Figs. S1, 1a). From day 5 to day 14 (P1) average TEP content in M2 and M3 decreased slightly yet significantly $(p<0.05)$ with the major decline in all mesocosms measured from day 5 to day 6 (Figs. 1, S1, Table S1 in the Supplement). From day 15 to 23 (P2) TEP concentrations in all mesocosms increased gradually $(p<0.05)$ over the subsequent 9 days to reach $381 \pm 39 \mu \mathrm{g} \mathrm{GXL}^{-1}$ on day 23 (Fig. 1, Table S1).

TEP concentrations in the lagoon waters were compared with those in the mesocosms. These showed a similar pattern of increase in TEP during P0 and P2, while the gradual decline in TEP concentrations during P1 was not statistically significant as observed in the mesocosms (Figs. 1, S1). In the lagoon waters, average TEP concentrations over the whole experimental period, day 2 to day 23, were $335 \pm$ $56 \mu \mathrm{g} \mathrm{GXL}^{-1}$. While temporal variations in the three mesocosms were generally statistically significant (Fig. 1, Table S1), the total TEP content calculated for each mesocosm and for an equivalent volume of lagoon water based on average mesocosm volume did not differ significantly when we assessed all data obtained during P1 and P2 (Fig. 2, $p>0.05$, Kruskal-Wallis analyses of variance). The lack of significant differences in total TEP content in the mesocosms throughout the experiment could reflect the contrasting processes of formation and breakdown that together maintain a relatively stable pool of available TEP.

Mechanical processes such as wave turbulence and tidal effects can influence TEP formation and breakdown (and resulting content) (Passow, 2002; Stoderegger and Herndl, 1999). Our results indicate no obvious effects of these parameters on TEP content as these were similar in the enclosed mesocosms and the outside lagoon (Figs. 1, 2). The difference between the TEP in the mesocosms and the lagoon water is significantly different immediately after $\mathrm{P}$ addition and only during $\mathrm{P} 1$ after $\mathrm{P}$ addition and subsequent utilization when declining $\mathrm{P}$ availability was correlated with increased
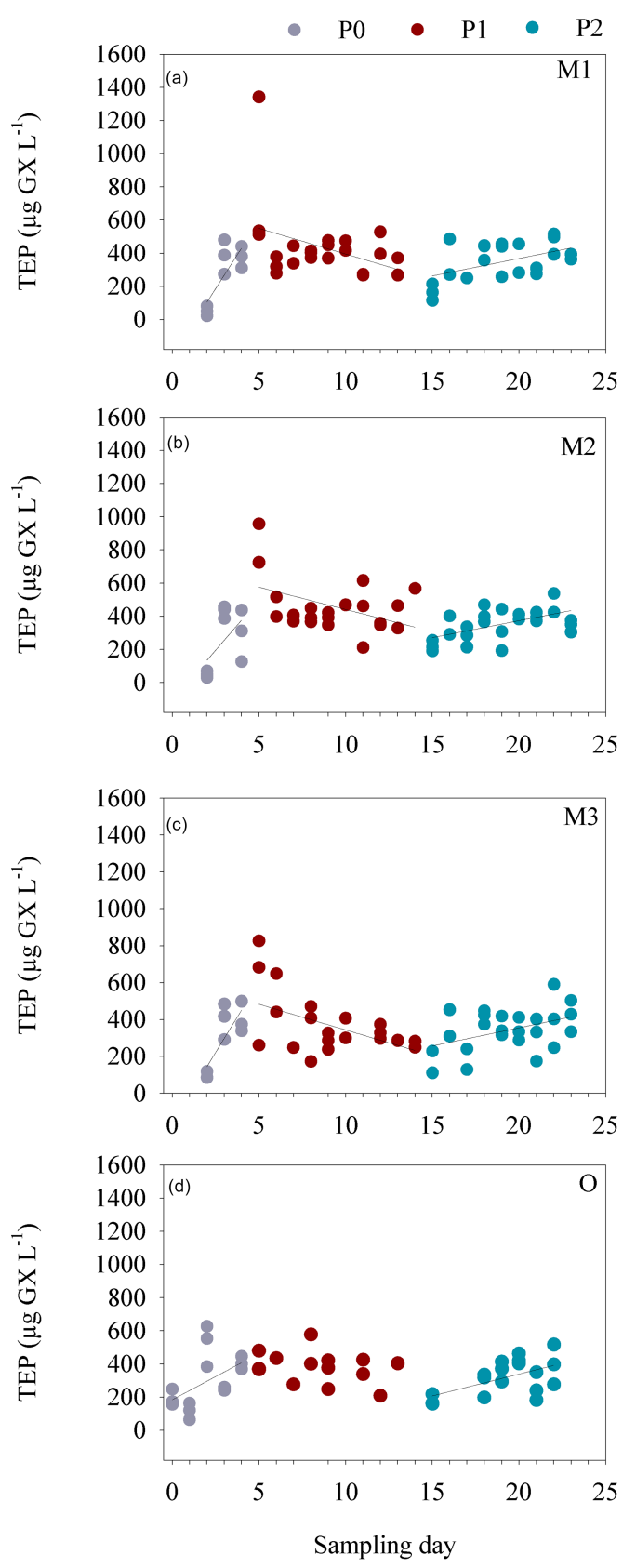

Figure 1. Temporal changes in transparent exopolymeric particle (TEP) concentrations $\left(\mu \mathrm{gXL}^{-1}\right)$ during the VAHINE mesocosm experiment. Data shown are from daily sampling of three depths $(1,6,12 \mathrm{~m})$ in each mesocosm. Data were analyzed according to the characterized phases of the experiment based on the diazotrophic communities that developed in the mesocosms (TurkKubo et al., 2015) and biogeochemical characteristics (Bonnet et al., 2016a). (a) Mesocosm 1 (M1), (b) Mesocosm 2 (M2), (c) Mesocosm 3 (M3), (d) samples from the lagoon waters outside of the mesocosms (O). Phases: P0 denotes days 2-4, P1 denotes days 514, P2 denotes days 15-23. Linear regressions (Pearson) of TEP for each of the phases are designated by a solid line, only when significant. Pearson correlation coefficients and significant values $(p<0.05)$ are represented in bold in Table S1. 


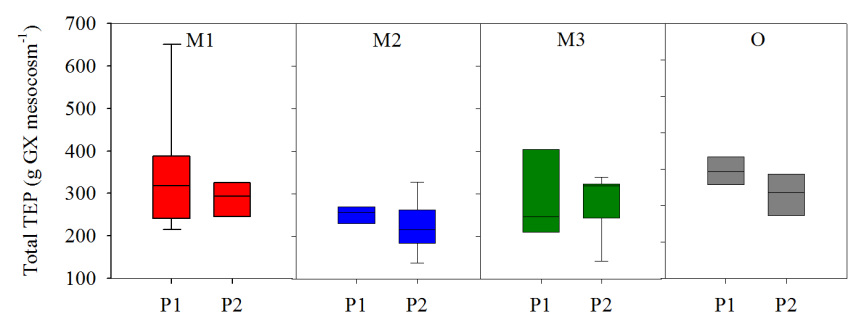

Figure 2. Total content of transparent exopolymeric particles (TEP) per mesocosm and in the lagoon waters surrounding the mesocosms. The average amount in $\mathrm{gGX}_{\text {mesocosm }}{ }^{-1}$ for the two periods of the experiment after DIP fertilization was calculated from the total daily amount based on concentrations measured at three depths and integrated for the specific volume per mesocosm or for an equivalent volume of lagoon water. Averages are represented in box plots as a function of two different phases: P1 = days 5-14 and P2 = days 15-23. Red, blue, green, and black denote Mesocosm 1 - M1, Mesocosm 2 - M2, Mesocosm 3 - M3, and outside lagoon $-\mathrm{O}$, respectively. Straight lines within the boxes mark the median. No significant differences were observed between the phases or between the three mesocosms and the outside lagoon (Kruskal-Wallis nonparametric analysis of variance; $p>0.05$ ).

TEP concentrations in the mesocosms. TEP concentrations from the lagoon water during P1 did not show any significant trend (Figs. 1, S1). In the mesocosms, the significant decline in TEP in the first days after $\mathrm{P}$ addition is probably due to two factors: (a) phytoplankton relieved of P stress will produce fewer TEP and increase growth rates; (b) bacteria will utilize the added $\mathrm{P}$ as well as TEP and other organic $\mathrm{C}$ sources to grow, so a higher TEP consumption and therefore a more significant decline in the mesocosms compared to the outside lagoon (see below Sect. 3.2).

The relative uniformity and stability of TEP within the $15 \mathrm{~m}$ water column of both the mesocosms and the lagoon waters reflects the homogeneity of the shallow lagoon system. The variability between the three depths was statistically insignificant in many of the other physical, chemical, and biological features of the mesocosms and the lagoon waters for temperature, salinity, inorganic nutrients (N, P, Si), POC, PON, POP, DOC, Chl $a$, and primary production and heterotrophic bacterial production (Berthelot et al., 2015; Bonnet et al., 2016a, b; Van Wambeke et al., 2016). In contrast to some marine systems where TEP concentrations were correlated with the vertical distribution of Chl $a$ or POC (Bar-Zeev et al., 2009, 2011; Engel, 2004; Ortega-Retuerta et al., 2009; Passow, 2002), the results we obtained here showed no correlation to the vertical (i.e. depth-related) autotrophic signatures. Moreover, the similar TEP concentrations at 1, 6, and $15 \mathrm{~m}$ do not support a subsurface maxima in TEP concentrations, stimulated by abiotic aggregation, at the seasurface top layer as has been reported at $1 \mathrm{~m}$ depth in different oceanic areas (Wurl et al., 2011). Abiotic processes of formation and breakdown can be influential; yet here we do not see a depth-correlated specific abiotic driver and TEP were evenly distributed within the $15 \mathrm{~m}$ water column for all mesocosms (Fig. S1).

\subsection{DIP availability, APA, and TEP content}

The average TEP concentrations we measured in the New Caledonian waters are comparable to TEP concentrations reported from other marine environments such as the eastern temperate-subarctic North Atlantic (Engel, 2004), the Ross Sea (Hong et al., 1997), western Mediterranean - Gulf of Cadiz and the Straits of Gibraltar (García et al., 2002; Prieto et al., 2006), the Gulf of Aqaba (northern Red Sea) (Bar-Zeev et al., 2009), in the northern Adriatic Sea (Radić et al., 2005), and in the New Caledonian lagoon (Mari et al., 2007; Rochelle-Newall et al., 2008).

While prediction as to the expected TEP concentrations with trophic or productive status is difficult (Beauvais et al., 2003), decreasing availability of dissolved nutrients such as nitrate and phosphate has been correlated with enriched TEP concentrations in both cultured phytoplankton and natural marine systems (Bar-Zeev et al., 2011; Brussaard et al., 2005; Engel et al., 2002; Urbani et al., 2005). In P-limited systems, low $\mathrm{Chl} a$ concentrations often reflect the nutrientstressed phytoplankton. As long as light and $\mathrm{CO}_{2}$ are available, limitation of essential nutrients results in an uncoupling between carbon fixation and growth during which the excess photosynthate can be used to produce carbon-rich compounds including TEP (Berman-Frank and Dubinsky, 1999; Mari et al., 2001; Rochelle-Newall et al., 2008). Moreover, as DIP availability declines, cells activate P-acquisition pathways and enzymes such as APA to access $\mathrm{P}$ from other sources. Thus, and based on previous data (Bar-Zeev et al., 2011), we hypothesized that TEP content would be negatively correlated with autotrophic biomass ( $\mathrm{Chl} a$ ) and PP and positively correlated with APA.

Mesocosm fertilization on the evening of day 4 enriched the system with tenfold higher DIP concentrations that were available for microbial utilization throughout the following 8-10 days (Berthelot et al., 2015; Bonnet et al., 2016b; Leblanc et al., 2016; Van Wambeke et al., 2016). Thus, when DIP concentrations were relatively sufficient during P1, no statistically significant relationship was observed between TEP and POP, DIP, $T_{\mathrm{DIP}}, \mathrm{Chl} a$, or PP (Table S2). This situation changed with the declining availability of DIP and the shift in the response of the system during P2 from day 15 to 23. During P2, high TEP concentrations were associated with decreasing DIP for each of the mesocosms, with an overall negative correlation $\left(R^{2}=0.23, n=23, p=0.02\right)$ (Fig. 3a). A similar negative trend was obtained between TEP and the turnover time of DIP ( $\left.T_{\mathrm{DIP}}\right)\left(R^{2}=0.28, n=26, p=0.006\right)$ (Fig. 3b).

In the Southwest Pacific Ocean, the critical DIP turnover time $\left(T_{\mathrm{DIP}}\right)$ required for single filaments of Trichodesmium to grow is 2 days (Moutin et al., 2005). Here $T_{\text {DIP }}$ values lower than 1 day, indicative of a strong DIP deficiency, were 

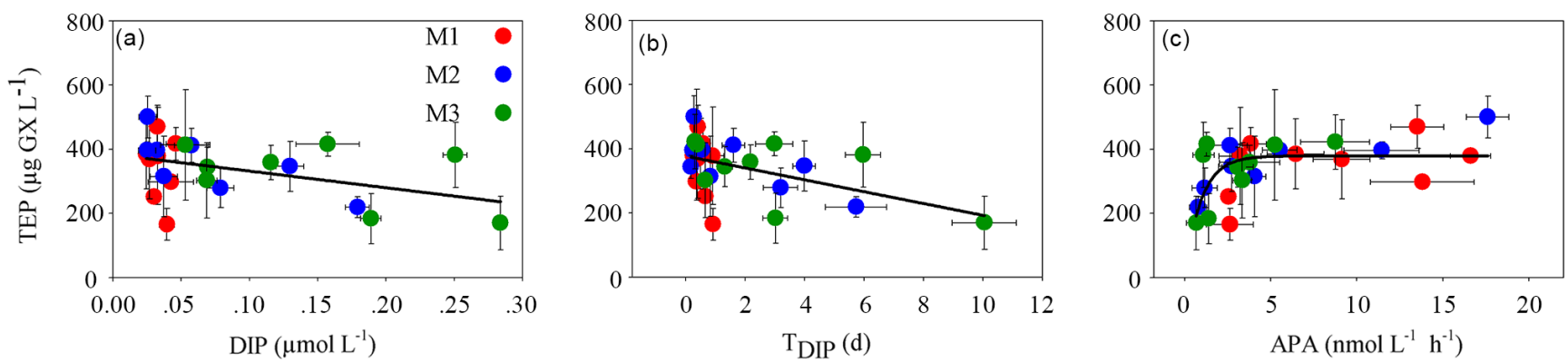

Figure 3. Relationships between the concentration of transparent exopolymeric particles (TEP), $\left(\mu g \mathrm{GXL}^{-1}\right)$ and (a) dissolved inorganic phosphorus DIP $\left(\mu \mathrm{mol} \mathrm{L}^{-1}\right)$, (b) turnover time of DIP $-T_{\text {DIP }}$ (days), and (c) alkaline phosphatase activity $\left(\right.$ APA) $\left(\mathrm{nmol} \mathrm{L}^{-1} \mathrm{~h}^{-1}\right)$ in the three mesocosms (M1- red; M2- blue; M3- green) during phase 2 (days 15-23). For (a) and (b) Pearson linear regressions yielded an $R^{2}$ of 0.54 , $n=23$ (TEP / DIP), and an $R^{2}$ of $0.52, n=26$ (TEP / T TP ), and for (c) $\log$-transformed $(\log (\mathrm{TEP}) / \log (\mathrm{APA}))$ with an $R^{2}$ of $0.68, n=25$. All correlations were significant $(p<0.05)$. Error bars represent \pm 1 standard deviation.

reached on day 14 in M1, day 19 for M2, and on day 21 for M3. The average $T_{\mathrm{DIP}}$ values during $\mathrm{P} 2$ were significantly different in each mesocosm, $T_{\mathrm{DIP}}$ of $0.5,1.8,3.9$ days for M1, M2, M3, respectively (Berthelot et al., 2015). Although turnover rates alone do not indicate $\mathrm{P}$ deficiency, increasing APA suggests that the cells were responding to $\mathrm{P}$ stress. APA increased rapidly in both M1 and M2 from day 18 (average for $\mathrm{M} 1$ and $\mathrm{M} 2$ during $\mathrm{P} 2 \sim 8 \pm 6 \mathrm{nmol} \mathrm{MUF}-$ Phyd $\mathrm{L}^{-1} \mathrm{~h}^{-1}$ ) and after day 21 in $\mathrm{M} 3$, illustrating a biological response of the microbial community to $\mathrm{P}$ stress (Van Wambeke et al., 2016). We did not specifically measure TEP production by autotrophic or heterotrophic plankton; yet, the significant (although indirect relationship) negative correlation of TEP with DIP concentrations and $T_{\mathrm{DIP}}$ (Fig. 3a, b) suggests that microbial responses to decreased DIP availability resulted from either (1) an increase in TEP synthesis through higher polysaccharide production rather than biomass which requires higher nutrients (Berman-Frank and Dubinsky, 1999; Wood and Van Valen, 1990) or (2) nutrient limitation, inducing greater breakdown of biomass and particulate organic matter (POM) (maybe via programmed cell death) and subsequent abiotic formation of TEP. We obtained a significant semi-logarithmic relationship between TEP and APA $\left(R^{2}=0.33, n=25, p=0.002\right)$ (Fig. 3c), which implies active TEP formation when DIP concentrations are reduced and APA increases until a saturating point, whereby any further increases in APA do not appear to impact TEP concentrations (Fig. 3c). This relationship may not always be valid, as APA in the lagoon waters was consistently higher at $1 \mathrm{~m}$ than APA measured at 6 and $12 \mathrm{~m}$ depths (Van Wambeke et al., 2016); yet TEP concentrations were uniform at all depths (Fig. S1).

\subsection{TEP and carbon pools}

The size range of TEP spans particles from 0.45 to $300 \mu \mathrm{m}$ (Alldredge et al., 1993; Bar-Zeev et al., 2015). TEP precursors $(0.05-0.45 \mu \mathrm{m}$ size $)$ are formed and broken down in the
DOC pool and thus essentially "TEP establish a bridge between the dissolved organic matter and the POM pool" (Engel, 2004). Our data show a generally stable contribution of TEP to the TOC pool. Excluding day 5, where TEP-C comprised $56.5 \pm 8 \%$ of TOC, the percentage of TEP-C was $28.9 \pm 9.3 \%$ and $27.0 \pm 7.2 \%$ of the TOC in all mesocosms and in the lagoon waters, respectively (Fig. 4a, b).

TEP concentrations can be directly and positively correlated with POC (Engel, 2004) and with DOC (OrtegaRetuerta et al., 2009); yet, TEP concentrations can also be negatively related to POC, indicative of low TEP production when POC concentrations are high (Bar-Zeev et al., 2011). In the mesocosms, a significant positive correlation between TEP concentrations and TOC was obtained for all three mesocosms only during $\mathrm{P} 2\left(R^{2}=0.75,0.73\right.$, 0.58 and $p<0.05$ for M1, M2, M3 respectively) (Fig. 4c, Table S2). This period coincided with the largest gain in total autotrophic and heterotrophic biomass and elevated $\mathrm{N}_{2}$ fixation, PP, and BP rates (Berthelot et al., 2015; Bonnet et al., 2016a; Van Wambeke et al., 2016).

Although TEP were significantly and positively correlated with TOC in the mesocosms during P2, this was not the case in the lagoon water (outside the mesocosms) (Table S2) or with either POC or DOC in any mesocosm for either P1 or P2 (Table S2). The absence of any significant correlation between TEP and POC was surprising as TEP are part of the POC pool comprising 40-60\% of the particulate combined carbohydrates in POC (Engel, 2004; Engel et al., 2012). Furthermore, we did not obtain any significant correlations of TEP and specific components of the dissolved organic matter such as fluorescent dissolved organic matter (FDOM) or chromophoric dissolved organic matter (CDOM) that was coupled to the dynamics of $\mathrm{N}_{2}$ fixation in the mesocosms (Tedetti et al., 2016). The lack of significant correlation could partially reflect methodological issues. In this experiment (and operationally according to published protocol; Passow and Alldredge, 1995), TEP were measured on $0.45 \mu \mathrm{m}$ filters; therefore Alcian Blue stained particles 

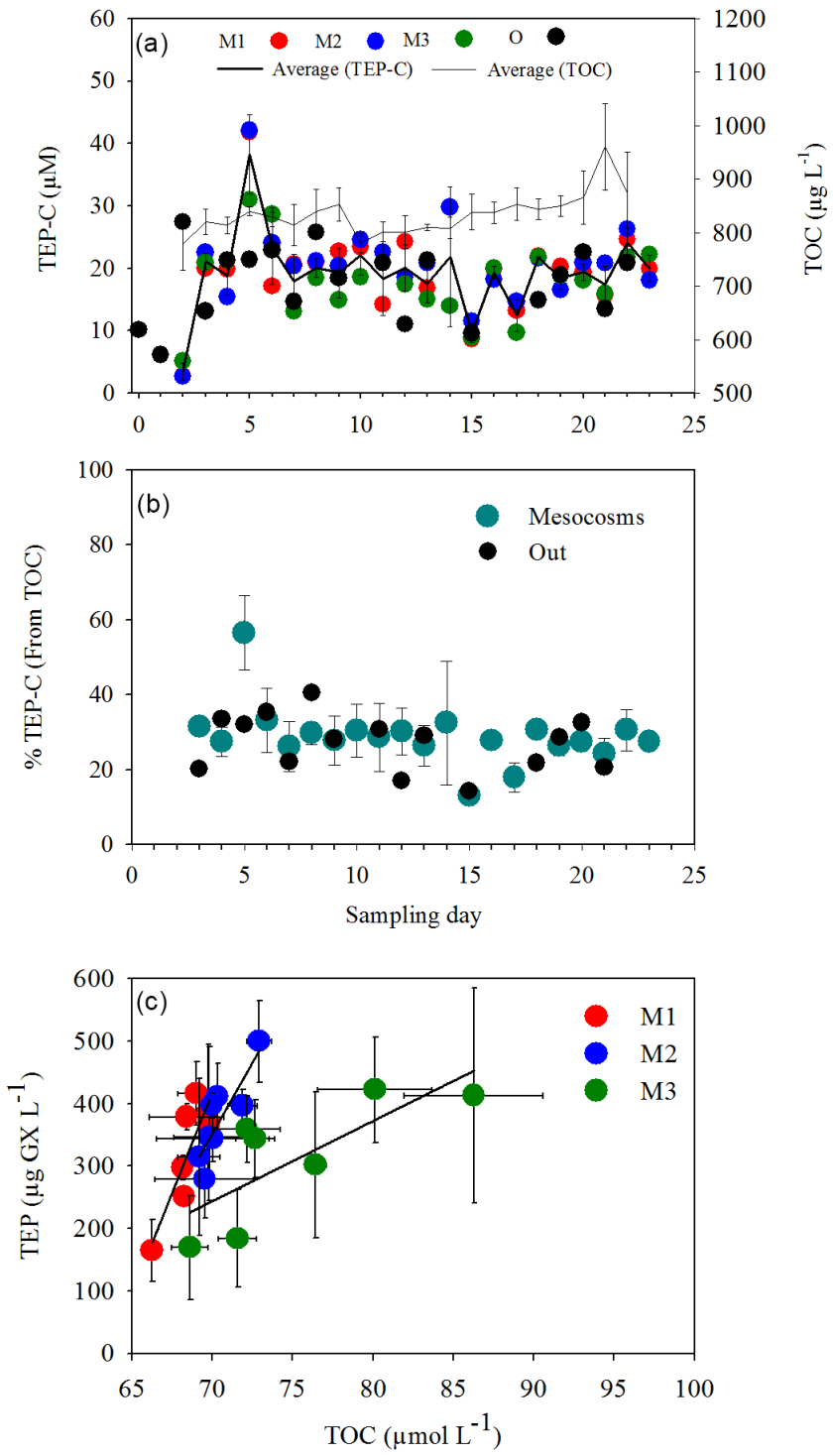

Figure 4. (a) Temporal dynamics of TEP carbon concentrations (TEP-C, $\mu \mathrm{M})$ in relationship to the average total organic carbon (TOC) $\left(\mu \mathrm{g} \mathrm{L}^{-1}\right)$ (thin black line) in the mesocosms (M1 - red dots, M2 - blue dots, M3 - green dots, and black dots - outside waters $(\mathrm{O})$. The black solid line designates TEP-C averaged for the three mesocosms (thick black line). TEP-C was measured from $6 \mathrm{~m}$ depths and calculated according to Engel (2000). (b) Temporal changes in the percentage of TEP-C in TOC (\%) in mesocosms (green dots), and the percentage of TEP-C in the lagoon waters (Out), (black dots). (c) Relationship between TEP concentrations $\left(\mu \mathrm{gXL}^{-1}\right)$ and TOC $\left(\mu \mathrm{mole} \mathrm{L}^{-1}\right)$, during phase 2 (days $15-23$ ) for Mesocosm 1 (M1, red dots), Mesocosm 2 (M2, blue dots), Mesocosm 3 (M3, green dots). Significant correlations were observed (Pearson) for all mesocosms. $R^{2}=0.75-\mathrm{M} 1,0.73-\mathrm{M} 2$, and $0.58-\mathrm{M} 3$ respectively, $n=7-8, p<0.05$. All statistics are detailed in Table S2, $(p=0.05, n=7-8)$. Error bars represent \pm 1 standard deviation. included particles $>0.45 \mu \mathrm{m}$, while POC was measured on $\mathrm{GF} / \mathrm{F}$ (nominal pore size $0.7 \mu \mathrm{m}$ ). DOC is typically considered for the $<0.45 \mu \mathrm{m}$ fraction (Thurman, 1985), although here no direct measurements of DOC were made and DOC was obtained by subtracting POC from TOC. Thus, DOC actually covered the $<0.7 \mu \mathrm{m}$ fraction. Our methodology therefore precluded determination of the smaller TEP precursors that would contribute to the DOC and colloidal pools (Villacorte et al., 2015). As such we probably overestimated TEP relative to POC and at the same time underestimated TEP contribution to the DOC pool (Bar-Zeev et al., 2009). The lacking correspondence between TEP concentrations and the pools of POC and DOC may also result from the uncoupling between formation and breakdown processes. Abiotic processes will modify relationships obtained between biotic TEP production and recycling (Wurl et al., 2011). Thus, it is feasible that especially during $\mathrm{P} 1$, abiotic factors predominated breaking down larger TEP particles into smaller TEP precursors that would be mobilized to the DOC pool, and would thus maintain a relatively stable TEP pool although we observed a positive increase in TEP with increased blooms of DDAs (see below Sect. 3.4.1).

\subsection{Production and utilization of TEP by primary and bacterial populations}

Typically, TEP are formed by diverse algal and bacterial species (Mari and Burd, 1998), yet are utilized mostly by bacteria and grazers as a rich $\mathrm{C}$ source (Azam and Malfatti, 2007; Bar-Zeev et al., 2015; Engel and Passow, 2001). Throughout this experiment (P1 and P2 stages) TEP were not significantly correlated to parameters related to autotrophic production such as total $\mathrm{Chl} a$, PP, non-diazotrophic diatom, or cyanobacterial abundance, or the growth and mortality rates of these populations (Table S2). Furthermore, during P1, no significant relationship between TEP and BA (total or specific for high and low nucleic acid bacteria - HNA or LNA respectively), BP, or division rates was noted in any of the mesocosms (Table S2).

This changed during P2 when TEP were positively correlated to the increasing BP for all three mesocosms (Pearson's correlation coefficient $R^{2}=0.63,0.66,0.69$ for M1, M2, and M3 respectively, $p<0.05$ ) (Fig. 5). This contrasted with the relationship in the lagoon water outside the mesocosms where no significant correlation between TEP and BP was noted (Table S2). During P2, TEP were also strongly and positively correlated to TOC, which significantly increased over this time period (Fig. 4c) due to the high production rates of both photosynthetic and heterotrophic bacterial populations. However, although BP and PP were positively associated during P2 (log-log transformation, Fig. 5 and in Van Wambeke et al., 2016), we found no direct correlation between TEP and PP for either linear (Table S2) or logtransformed regression (not shown). This coupling between PP and BP, while a concurrent association between TEP and 


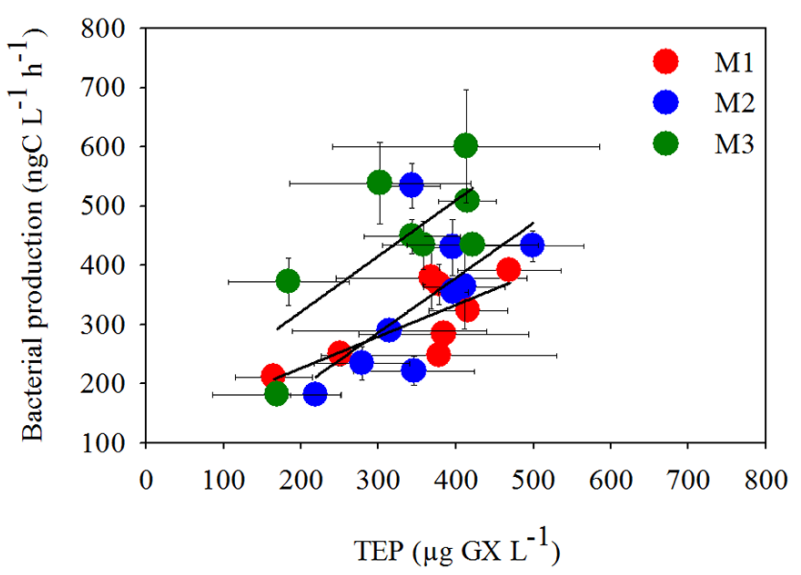

Figure 5. Relationship between heterotrophic bacterial production (BP) $\left(\mathrm{ng} \mathrm{CL} \mathrm{L}^{-1} \mathrm{~h}^{-1}\right)$ and TEP concentrations $\left(\mu \mathrm{GXL}^{-1}\right)$ during phase 2 (days 15-23) when BP increased following the enhanced PP (Van Wambeke et al., 2016), for Mesocosm 1 (M1, red dots), Mesocosm 2 (M2, blue dots), Mesocosm 3 (M3, green dots). Pearson's linear regressions yielded $R^{2}=0.57$ for M1, 0.42 for M2, and 0.56 for M3 respectively. Significant correlations were observed for all mesocosms and are detailed in Table S2. Error bars represent \pm 1 standard deviation.

BP occurred during P2, indicates TEP may have been utilized by bacteria as a carbon source (Azam, 1998; Ziervogel et al., 2014) or provided a suitable niche for aggregation and proliferation of heterotrophic bacteria.

\section{TEP and diazotrophic populations}

Overall $\mathrm{N}_{2}$ fixation rates were not significantly correlated with TEP concentrations at any time throughout the experiment (Table S2); neither could we discern any direct evidence of TEP providing a carbon source for heterotrophic diazotrophs as was found previously in the Gulf of Aqaba where these organisms contributed greatly to the $\mathrm{N}_{2}$ fixation rates (Rahav et al., 2015). Indeed, no relationship was found between TEP concentrations and the abundance or growth rates of the heterotrophic diazotrophs $\gamma$-24774A11 (Moisander et al., 2014). Although these organisms were present throughout the experiment, and increased $\sim$ fourfold from day 9 to 15 especially in M3, they contributed only a small fraction to the total diazotrophic biomass and $\mathrm{N}_{2}$ fixation rates (Turk-Kubo et al., 2015).

However, discerning individual diazotroph populations revealed some species-specific correspondence to TEP at certain periods during the experiment. For example, throughout the experiment, net growth rates (i.e., based on differences of nifH copies $\mathrm{L}^{-1}$ from day to day) of the DDA Richelia (Het-1) associated with Rhizosolenia (Turk-Kubo et al., 2015) temporally paralleled TEP concentrations in all mesocosms (Fig. 6a, b, c, e, f). During both P1 and P2, TEP concentrations were positively correlated with the net growth rates of Het-1 $\left(R^{2}=0.6, P=0.0001, n=19\right.$ for all meso- cosms) (Fig. 6d). Although the DDAs dominated the diazotroph community during P1 (primarily Het-1), their overall contribution to diatom biomass in the mesocosm was low, with only 2-8\% of all diatom biomass (Leblanc et al., 2016). We did not observe an overall relationship between TEP and total diatom biomass throughout VAHINE although diatoms are well known for their TEP production especially when nutrients are limiting and growth rates decline (Fukao et al., 2010; Urbani et al., 2005). Thus, the positive association between TEP and the growth rates of Het-1 and not of the other DDAs Het-2 and Het-3 is intriguing.

TEP were also associated with the growth rates of the unicellular UCYN-C diazotrophs that bloomed during P2 and dominated the $\mathrm{N}_{2}$ fixation rates of this period (Berthelot et al., 2015; Turk-Kubo et al., 2015). During P2, UCYN-C net growth rates were positively correlated with increasing TEP concentrations $\left(R^{2}=0.65,0.83,0.88\right.$ for $\mathrm{M} 1, \mathrm{M} 2, \mathrm{M} 3$ respectively, $p<0.05$ ). Furthermore, UCYN-C probably produced an organic matrix possibly also comprised of TEP that aided the formation of large aggregates $(100-500 \mu \mathrm{m})$ (Fig. 6g, h). These aggregates were predominantly responsible for the enhanced export production $(22.4 \pm 5 \%$ of exported POC) (Bonnet et al., 2016a; Knapp et al., 2015). High TEP content was obtained from sediment traps on days 15 and 16 (Fig. S1), corresponding to the height of the UCYN-C bloom in the mesocosms (Turk-Kubo et al., 2015) and substantiating the role of TEP in facilitating export flux in the New Caledonian lagoon (Mari et al., 2007).

\section{Conclusions}

Although physically separated from the surrounding lagoon, TEP formation and breakdown was difficult to tease out in the VAHINE mesocosms where abiotic drivers (turbulence, shear forces, chemical coagulation) and biotic processes (algal and bacterial production and utilization) maintained an apparently constant pool of TEP within the TOC. Total TEP content was generally stable throughout the experimental period of 23 days and comprised $\sim 28 \%$ of the TOC in the mesocosms and lagoon, with uniform distribution in the three sampled depths of the $15 \mathrm{~m}$ deep-water column.

TEP concentrations appeared to be impacted indirectly via changes in DIP availability as it was biologically consumed in the mesocosms after fertilization. Thus, declining $\mathrm{P}$ availability (low DIP, rapid $T_{\mathrm{DIP}}$, and increased APA) was associated with higher TEP content in all mesocosms. TEP concentrations were also positively associated with net growth rates of two important diazotrophic groups: the DDA Richelia-Rhizosolenia (Fig. 6e, f), during P1 and P2 (excluding days 21-23); and UCYN-C diazotrophs which bloomed during P2. High TEP content in the sediment traps during the UCYN-C bloom indicates that TEP may have been part of the organic matrix associated with the large aggre- 
(a)
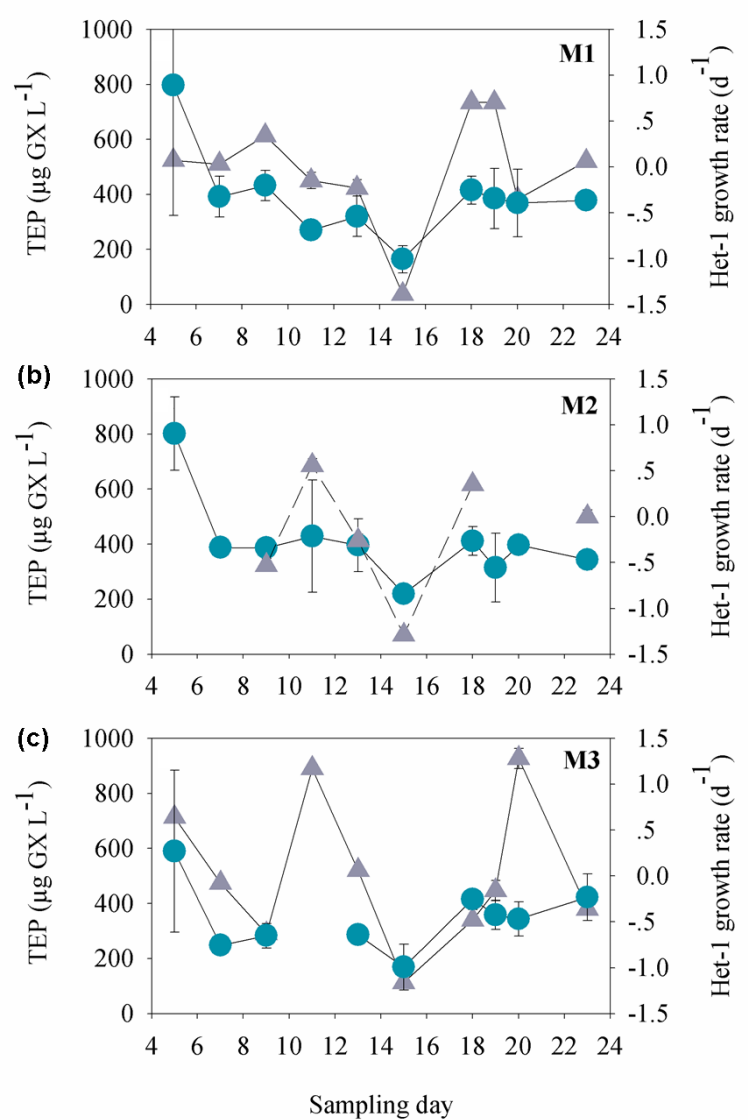

(d)
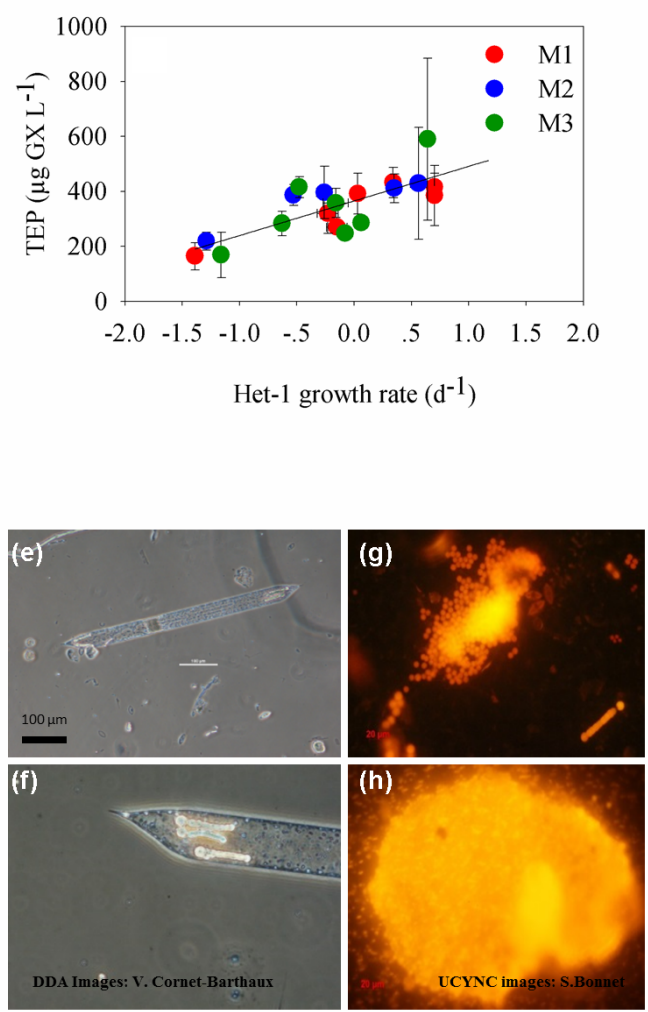

Figure 6. Temporal changes in TEP concentrations and Het-1 net growth rates $\left(\mathrm{d}^{-1}\right.$ ), (gray triangles) for (a) Mesocosm 1 (M1), (b) Mesocosm 2 (M2), and (c) Mesocosm 3 (M3). TEP concentrations were averaged from the three depths sampled per mesocosm (green circles). Het-1 net growth rates were calculated based on changes of nifH copies $\mathrm{L}^{-1}$ (Turk-Kubo et al., 2015) measured every other day. (d) Relationship between TEP concentrations $\left(\mu \mathrm{gGXL}{ }^{-1}\right)$ and Het-1 growth rate $\left(\mathrm{d}^{-1}\right)$ for all three mesocosms. Significant correlations were observed (Pearson) from all mesocosms together. $R^{2}=0.60, p=0.0001, n=19$. Error bars represent \pm 1 standard deviation. (e, f) Epifluorescent microscopical images of the diatom-diazotroph association Richelia-Rhizosolenia identified by Het-1 abundance. Images by V. Cornet-Barthaux. $(\mathbf{g}, \mathbf{h})$ The diazotroph UCYN-C which bloomed and formed large aggregates (comprised also of TEP) that enhanced vertical flux and export production during P2. Images by S. Bonnet.

gates of UCYN-C that were exported to the sediment traps (Fig. 6g, h).

TEP may have also provided bacteria with a rich organic carbon source, especially during P2 when higher BP (stimulated by the higher PP) was positively correlated with higher TEP concentrations. High production of TEP also occurred in the lagoon water outside the mesocosms on day 23 during the decline of a short-lived dense surface bloom of the diazotrophic Trichodesmium (Spungin et al., 2016). Our results emphasize the complexities of the natural system and suggest that to understand the role of compounds such as TEP, and their contribution to the DOC and POC pools, a wider perspective and range of methodologies should be undertaken to examine and characterize the different components of marine gels (not only carbohydrate-based) (Bar-Zeev et al., 2015; Verdugo, 2012).

\section{The Supplement related to this article is available online at doi:10.5194/bg-13-3793-2016-supplement.}

Author contributions. Ilana Berman-Frank conceived and designed the investigation of TEP dynamics within the VAHINE project. Thierry Moutin, France Van Wambeke, Ilana Berman-Frank, Dina Spungin, and Eyal Rahav participated in the experiment and performed analyses of samples and data; Kendra Turk-Kubo analyzed diazotrophic populations. Ilana Berman-Frank and Dina Spungin wrote the manuscript with contributions from all co-authors. 
Acknowledgements. Many thanks to Sophie Bonnet who created, designed, and successfully executed the VAHINE project. The participation of Ilana Berman-Frank, Dina Spungin, and Eyal Rahav in the VAHINE experiment was supported by the German-Israeli Research Foundation (GIF), project number 1133-13.8/2011, through a collaborative grant (no. 2012/3-9246) to Ilana Berman-Frank and Sophie Bonnet and C. Dupouy from the Israel Ministry of Science and Technology (MOST) and the High Council for Science and Technology (HCST) France, and a grant (no. 2008048) from the United States-Israel Binational Science Foundation (BSF) to Ilana Berman-Frank. Funding for this research was provided by the Agence Nationale de la Recherche (ANR starting grant VAHINE ANR-13-JS06-0002), INSU-LEFE-CYBER program, GOPS, IRD, and M.I.O. The authors thank the captain and crew of the R/V Alis, the SEOH divers service from the IRD research center of Noumea (E. Folcher, B. Bourgeois, and A. Renaud) and from the Observatoire Océanologique de Villefranche-sur-mer (OOV, J. M. Grisoni), and the technical service and support of the IRD research center of Noumea. Thanks are also expressed to C. Guieu, F. Louis, and J. M. Grisoni from OOV for mesocosm design and deployment advice. Special thanks to H. Berthelot and all other participants and principal investigators of the project for the joint efforts and for making their data available for further analyses and to the reviewers who helped improve the manuscript. This work is in partial fulfillment of the requirements for a $\mathrm{PhD}$ thesis for Dina Spungin at Bar Ilan University.

Edited by: S. Bonnet

\section{References}

Alldredge, A. L., Passow, U., and Logan, B. E.: The abundance and significance of a class of large, transparent organic particles in the ocean., Deep-Sea Res., 40, 1131-1140, 1993.

Aminot, A. and Kérouel, R.: Dosage automatique des nutriments dans les eaux marines: Méthodes en flux continu, Editions Quae, Netherlands, 2007.

Azam, F.: Microbial control of oceanic carbon flux: The plot thickens, Science, 280, 694-696, 1998.

Azam, F. and Malfatti, F.: Microbial structuring of marine ecosystems, Nat. Rev. Microbiol., 5, 782-791, 2007.

Azetsu-Scott, K. and Passow, U.: Ascending marine particles: significance of transparent exopolymer particles (TEP) in the upper ocean, Limnol. Oceanogr., 49, 741-748, 2004.

Bar-Zeev, E., Berman-Frank, I., Liberman, B., Rahav, E., Passow, U., and Berman, T.: Transparent exopolymer particles: Potential agents for organic fouling and biofilm formation in desalination and water treatment plants, Desalination and Water Treatment, 3, 136-142, 2009.

Bar-Zeev, E., Berman, T., Rahav, E., Dishon, G., Herut, B., Kress, N., and Berman-Frank, I.: Transparent exopolymer particle (TEP) dynamics in the eastern Mediterranean Sea, Mar. Ecol.Prog. Ser., 431, 107-118, doi:10.3354/meps09110, 2011.

Bar-Zeev, E., Passow, U., Romero-Vargas Castrilloìn, S., and Elimelech, M.: Transparent exopolymer particles: from aquatic environments and engineered systems to membrane biofouling, Environ. Sci. Technol., 49, 691-707, 2015.
Beauvais, S., Pedrotti, M. L., Villa, E., and Lemee, R.: Transparent exopolymer particle (TEP) dynamics in relation to trophic and hydrological conditions in the NW Mediterranean Sea, Mar. Ecol.-Prog. Ser., 262, 97-109, 2003.

Benavides, M., Moisander, P. H., Berthelot, H., Dittmar, T., Grosso, O., and Bonnet, S.: Mesopelagic $\mathrm{N}_{2}$ Fixation Related to Organic Matter Composition in the Solomon and Bismarck Seas (Southwest Pacific), PLoS ONE, 10, e0143775, doi:10.1371/journal.pone.0143775, 2015.

Berman-Frank, I. and Dubinsky, Z.: Balanced growth in aquatic plants: Myth or reality? Phytoplankton use the imbalance between carbon assimilation and biomass production to their strategic advantage, Bioscience, 49, 29-37, 1999.

Berman-Frank, I., Rosenberg, G., Levitan, O., Haramaty, L., and Mari, X.: Coupling between autocatalytic cell death and transparent exopolymeric particle production in the marine cyanobacterium Trichodesmium, Environ. Microbiol., 9, 1415-1422, 2007.

Berthelot, H., Moutin, T., L'Helguen, S., Leblanc, K., Hélias, S., Grosso, O., Leblond, N., Charrière, B., and Bonnet, S.: Dinitrogen fixation and dissolved organic nitrogen fueled primary production and particulate export during the VAHINE mesocosm experiment (New Caledonia lagoon), Biogeosciences, 12, 40994112, doi:10.5194/bg-12-4099-2015, 2015.

Biegala, I. C. and Raimbault, P.: High abundance of diazotrophic picocyanobacteria $(<3 \mu \mathrm{m})$ in a Southwest Pacific coral lagoon, Aquat. Microb. Ecol., 51, 45-53, 2008.

Bonnet, S., Berthelot, H., Turk-Kubo, K., Fawcett, S., Rahav, E., L'Helguen, S., and Berman-Frank, I.: Dynamics of $\mathrm{N}_{2}$ fixation and fate of diazotroph-derived nitrogen in a low-nutrient, low-chlorophyll ecosystem: results from the VAHINE mesocosm experiment (New Caledonia), Biogeosciences, 13, 2653-2673, doi:10.5194/bg-13-2653-2016, 2016a.

Bonnet, S., Moutin, T., Rodier, M., Grisoni, J.-M., Louis, F., Folcher, E., Bourgeois, B., Boré, J.-M., and Renaud, A.: Introduction to the project VAHINE: VAriability of vertical and tropHIc transfer of diazotroph derived $\mathrm{N}$ in the south wEst Pacific, Biogeosciences, 13, 2803-2814, doi:10.5194/bg-13-28032016, 2016b.

Brussaard, C., Mari, X., Van Bleijswijk, J., and Veldhuis, M.: A mesocosm study of Phaeocystis globosa (Prymnesiophyceae) population dynamics: II. Significance for the microbial community, Harmful Algae, 4, 875-893, 2005.

Capone, D. G.: Marine nitrogen fixation: what's the fuss?, Curr. Opin. Microbiol., 4, 341-348, 2001.

Duhamel, S., Zeman, F., and Moutin, T.: A dual-labeling method for the simultaneous measurement of dissolved inorganic carbon and phosphate uptake by marine planktonic species, Limnol. Oceanogr., 4, 416-425, 2006.

Dupouy, C., Neveux, J., Subramaniam, A., Mulholland, M. R., Montoya, J. P., Campbell, L., Capone, D. G., and Carpenter, E. J.: Satellite captures Trichodesmium blooms in the SouthWestern Tropical Pacific, EOS T. Am. Geophys. Un., 81, 13-16, 2000.

Engel, A.: The role of transparent exopolymer particles (TEP) in the increase in apparent particle stickiness $(\alpha)$ during the decline of a diatom bloom, J. Plankton Res., 22, 485-497, 2000.

Engel, A.: Distribution of transparent exopolymer particles (TEP) in the northeast Atlantic Ocean and their potential significance for aggregation processes, Deep-Sea Res. Pt. I, 51, 83-92, 2004. 
Engel, A. and Passow, U.: Carbon and nitrogen content of transparent exopolymer particles (TEP) in relation to their Alcian Blue adsorption, Mar. Ecol.-Prog. Ser., 219, 1-10, 2001.

Engel, A., Goldthwait, S., Passow, U., and Alldredge, A.: Temporal decoupling of carbon and nitrogen dynamics in a mesocosm diatom bloom, Limnol. Oceanogr., 47, 753-761, 2002.

Engel, A., Harlay, J., Piontek, J., and Chou, L.: Contribution of combined carbohydrates to dissolved and particulate organic carbon after the spring bloom in the northern Bay of Biscay (NorthEastern Atlantic Ocean), Cont. Shelf Res., 45, 42-53, 2012.

Eppley, R. W. and Peterson, B. J.: Particulate organic-matter flux and planktonic new production in the deep ocean, Nature, 282, 677-680, doi:10.1038/282677a0, 1979.

Falkowski, P. G.: Evolution of the nitrogen cycle and its influence on the biological sequestration of $\mathrm{CO}_{2}$ in the ocean, Nature, 387 , 272-275, 1997.

Fukao, T., Kimoto, K., and Kotani, Y.: Production of transparent exopolymer particles by four diatom species, Fisheries Sci., 76, 755-760, 2010.

García, C., Prieto, L., Vargas, M., Echevarría, F., Garcia-Lafuente, J., Ruiz, J., and Rubin, J.: Hydrodynamics and the spatial distribution of plankton and TEP in the Gulf of Cadiz (SW Iberian Peninsula), J. Plankton Res., 24, 817-833, 2002.

Garcia, N., Raimbault, P., and Sandroni, V.: Seasonal nitrogen fixation and primary production in the Southwest Pacific: nanoplankton diazotrophy and transfer of nitrogen to picoplankton organisms, Mar. Ecol.-Prog. Ser., 343, 25-33, doi:10.3354/meps06882, 2007.

Grossart, H. P., Simon, M., and Logan, B. E.: Formation of macroscopic organic aggregates (lake snow) in a large lake: The significance of transparent exopolymer particles, plankton, and zooplankton, Limnol. Oceanogr., 42, 1651-1659, 1997.

Hong, Y., Smith, W. O., and White, A. M.: Studies on transparent exopolymer particles (TEP) produced in the ross sea (antarctica) and by Phaeocystis antarctica (prymnesiophyceae), J. Phycol., 33, 368-376, 1997.

Hoppe, H. G.: Significance of exoenzymatic activities in the ecology of brackish water: measurements by means of methylumbelliferyl-substrates, Mar. Ecol.-Prog. Ser., 11, 299308, 1983.

Kirchman, D. L.: Leucine incorporation as a measure of biomass production by heterotrophic bacteria, in: Current Methods in Aquatic Microbial Ecology, edited by: Kemp, P., Sherr, B. E., Sherr, E. B., and Cole, J. J., Lewis Publishers, Boca Raton, FL, USA, 509-512, 1993.

Knapp, A. N., Fawcett, S. E., Martínez-Garcia, A., Leblond, N., Moutin, T., and Bonnet, S.: Nitrogen isotopic evidence for a shift from nitrate- to diazotroph-fueled export production in VAHINE mesocosm experiments, Biogeosciences Discuss., 12, 1990119939, doi:10.5194/bgd-12-19901-2015, 2015.

Leblanc, K., Cornet, V., Caffin, M., Rodier, M., Desnues, A., Berthelot, H., Turk-Kubo, K., and Heliou, J.: Phytoplankton community structure in the VAHINE MESOCOSM experiment, Biogeosciences Discuss., doi:10.5194/bg-2015-605, in review, 2016.

Logan, B. E., Passow, U., Alldredge, A. L., Grossartt, H.-P., and Simont, M.: Rapid formation and sedimentation of large aggregates is predictable from coagulation rates (half-lives) of transparent exopolymer particles (TEP), Deep-Sea Res. Pt. II, 42, 203-214, 1995.
Mari, X. and Burd, A.: Seasonal size spectra of transparent exopolymeric particles (TEP) in a coastal sea and comparison with those predicted using coagulation theory, Mar. Ecol.-Prog. Ser., 163, 63-76, 1998.

Mari, X., Beauvais, S., Lemée, R., and Pedrotti, M. L.: NonRedfield $\mathrm{C}: \mathrm{N}$ ratio of transparent exopolymeric particles in the northwestern Mediterranean Sea, Limnol. Oceanogr., 46, 18311836, 2001.

Mari, X., Kerros, M. E., and Weinbauer, M. G.: Virus attachment to transparent exopolymeric particles along trophic gradients in the southwestern lagoon of New Caledonia, Appl. Environ. Microb., 73, 5245-5252, doi:10.1128/aem.00762-07, 2007.

Mohr, W., Grosskopf, T., Wallace, D. W., and LaRoche, J.: Methodological underestimation of oceanic nitrogen fixation rates, PLoS ONE, 5, e12583, doi:10.1371/journal.pone.0012583, 2010.

Moisander, P. H., Serros, T., Paerl, R. W., Beinart, R. A., and Zehr, J. P.: Gammaproteobacterial diazotrophs and nifH gene expression in surface waters of the South Pacific Ocean, ISME J., 8, 1962-1973, 2014.

Moutin, T., Thingstad, T. F., Van Wambeke, F., Marie, D., Slawyk, G., Raimbault, P., and Claustre, H.: Does competition for nanomolar phosphate supply explain the predominance of the cyanobacterium Synechococcus?, Limnol. Oceanogr., 47, 15621567, 2002.

Moutin, T., Van Den Broeck, N., Beker, B., Dupouy, C., Rimmelin, P., and Le Bouteiller, A.: Phosphate availability controls Trichodesmium spp. biomass in the SW Pacific Ocean, Mar. Ecol.Prog. Ser., 297, 15-21, 2005.

Mulholland, M. R. and Capone, D. G.: The nitrogen physiology of the marine $\mathrm{N}_{2}$-fixing cyanobacteria Trichodesmium spp., Trends Plant Sci., 5, 148-153, 2000.

Ortega-Retuerta, E., Reche, I., Pulido-Villena, E., Agustí, S., and Duarte, C. M.: Uncoupled distributions of transparent exopolymer particles (TEP) and dissolved carbohydrates in the Southern Ocean, Mar. Chem., 115, 59-65, 2009.

Passow, U.: Transparent exopolymer particles (TEP) in aquatic environments, Prog. Oceanogr., 55, 287-333, 2002.

Passow, U. and Alldredge, A. L.: A dye binding assay for the spectrophotometeric measurement of transparent exopolymer particles (TEP), Limnol. Oceanogr., 40, 1326-1335, 1995.

Postgate, J. R. and Eady, R. R.: The evolution of biological nitrogen fixation, in: Nitrogen Fixation: One Hundred Years After, edited by: Bothe, H., DeBruijn, F. J., Newton, W. E., Gustav Fischer, Stuttgart, 31-40, 1988.

Prieto, L., Navarro, G., Cozar, A., Echevarria, F., and García, C. M.: Distribution of TEP in the euphotic and upper mesopelagic zones of the southern Iberian coasts, Deep-Sea Res. Pt. II, 53, 1314 1328, 2006.

Radić, T., Degobbis, D., Fuks, D., Radić, J., and Đakovac, T.: Seasonal cycle of transparent exopolymer particles' formation in the northern Adriatic during years with (2000) and without mucilage events (1999), Fresen. Environ. Bull., 14, 224-230, 2005.

Rahav, E., Bar-Zeev, E., Ohayion, S., Elifantz, H., Belkin, N., Herut, B., Mulholland, M. R., and Berman-Frank, I. R.: Dinitrogen fixation in aphotic oxygenated marine environments, Frontiers in Microbiology, 4, 227, doi:10.3389/fmicb.2013.00227, 2013.

Rahav, E., Herut, B., Mulholland, M. R., Belkin, N., Elifantz, H., and Berman-Frank, I.: Heterotrophic and autotrophic contribu- 
tion to dinitrogen fixation in the Gulf of Aqaba, Mar. Ecol.-Prog. Ser., 522, 67-77, 2015.

Rochelle-Newall, E., Torreton, J.-P., Mari, X., and Pringault, O.: Phytoplankton-bacterioplankton coupling in a subtropical South Pacific coral reef lagoon, Aquat. Microb. Ecol., 50, 221-229, 2008.

Rodier, M. and Le Borgne, R.: Population dynamics and environmental conditions affecting Trichodesmium spp. (filamentous cyanobacteria) blooms in the south-west lagoon of New Caledonia, J. Exp. Mar. Biol. Ecol., 358, 20-32, doi:10.1016/j.jembe.2008.01.016, 2008.

Rodier, M. and Le Borgne, R.: Population and trophic dynamics of Trichodesmium thiebautii in the SE lagoon of New Caledonia. Comparison with T. erythraeum in the SW lagoon, Mar. Pollut. Bull., 61, 349-359, doi:10.1016/j.marpolbul.2010.06.018, 2010.

Smith, D. C. and Azam, F.: A simple, economic method for measuring bacterial protein synthesis rates in seawater using ${ }^{3} \mathrm{H}$-leucine, Marine Microbial Food Webs, 6, 107-114, 1992.

Spungin, D., Pfreundt, U., Berthelot, H., Bonnet, S., AlRoumi, D., Natale, F., Hess, W. R., Bidle, K. D., and Berman-Frank, I.: Mechanisms of Trichodesmium bloom demise within the New Caledonia Lagoon during the VAHINE mesocosm experiment, Biogeosciences Discuss., doi:10.5194/bg-2015-613, in review, 2016.

Stam, H., Stouthamer, A. H., and van Verseveld, H. W.: Hydrogen metabolism and energy costs of nitrogen fixation, FEMS Microbiol. Rev., 46, 73-92, 1987.

Stoderegger, K. E. and Herndl, G. J.: Production of exopolymer particles by marine bacterioplankton under contrasting turbulence conditions, Mar. Ecol.-Prog. Ser., 189, 9-16, 1999.

Tedetti, M., Marie, L., Röttgers, R., Rodier, M., Van Wambeke, F., Helias, S., Caffin, M., Cornet-Barthaux, V., and Dupouy, C.: Evolution of dissolved and particulate chromophoric materials during the VAHINE mesocosm experiment in the New Caledonian coral lagoon (south-west Pacific), Biogeosciences, 13, 3283-3303, doi:10.5194/bg-13-3283-2016, 2016.

Thurman, E.: Organic Geochemistry of Natural Waters, Martinus Nijhoff/Dr W. Junk Publishers, Dordrecht, Netherlands, 1985.

Turk-Kubo, K. A., Frank, I. E., Hogan, M. E., Desnues, A., Bonnet, S., and Zehr, J. P.: Diazotroph community succession during the VAHINE mesocosm experiment (New Caledonia lagoon), Biogeosciences, 12, 7435-7452, doi:10.5194/bg-12-7435-2015, 2015.
Urbani, R., Magaletti, E., Sist, P., and Cicero, A. M.: Extracellular carbohydrates released by the marine diatoms Cylindrotheca closterium, Thalassiosira pseudonana and Skeletonema costatum: Effect of P-depletion and growth status, Sci. Total Environ., 353, 300-306, 2005.

Van Wambeke, F., Pfreundt, U., Barani, A., Berthelot, H., Moutin, T., Rodier, M., Hess, W. R., and Bonnet, S.: Heterotrophic bacterial production and metabolic balance during the VAHINE mesocosm experiment in the New Caledonia lagoon, Biogeosciences, 13, 3187-3202, doi:10.5194/bg-13-3187-2016, 2016.

Verdugo, P.: Marine microgels, Annual Review of Marine Science, 4, 375-400, 2012.

Verdugo, P. and Santschi, P. H.: Polymer dynamics of DOC networks and gel formation in seawater, Deep-Sea Res. Pt. II, 57, 1486-1493, 2010.

Villacorte, L. O., Ekowati, Y., Calix-Ponce, H. N., Schippers, J. C., Amy, G. L., and Kennedy, M. D.: Improved method for measuring transparent exopolymer particles (TEP) and their precursors in fresh and saline water, Water Res., 70, 300-312, 2015.

Wood, A. and Van Valen, L.: Paradox lost? On the release of energyrich compounds by phytoplankton, Microbial Food Webs, 4, 103-116, 1990.

Wurl, O., Miller, L., and Vagle, S.: Production and fate of transparent exopolymer particles in the ocean, J. Geophys. Res., 116, C00H13, doi:10.1029/2011JC007342, 2011.

Zehr, J. P. and Kudela, R. M.: Nitrogen Cycle of the Open Ocean: From Genes to Ecosystems, Annual Review of Marine Science, 3, 197-225, 2011.

Zhou, J., Mopper, K., and Passow, U.: The role of surface-active carbohydrates in the formation of transparent exopolymer particles by bubble adsorption of seawater, Limnol. Oceanogr., 43, 1860-1871, 1998.

Ziervogel, K., D'souza, N., Sweet, J., Yan, B., and Passow, U.: Natural oil slicks fuel surface water microbial activities in the northern Gulf of Mexico, Frontiers in Microbiology, 5, 188, doi:10.3389/fmicb.2014.00188, 2014. 